\title{
CentenNial Lecture \\ THE RELATIONSHIP OF PARLIAMENT AND THE COURTS: A TENTATIVE THOUGHT OR TWO FOR THE NEW MILLENNIUM
}

Justice E W Thomas*

This paper was delivered as the Victoria University of Wellington Law Faculty's Centennial Lecture on 30 June 1999.

\section{INTRODUCTION}

I am both honoured and humbled by the invitation to give the Victoria University of Wellington Law Faculty's Centennial Lecture. Although I have, since my days at this great Law School, devoted myself to the goal of achieving justice under the law, I very much fear that I may not do justice to this occasion.

My misgivings, which are all-pervasive, extend even to the topic. When Professor McLauchlan, the organiser of this Centennial week, asked for my suggestions I eventually, and after much thought, returned with two titles. The first:

The Tax Implications for Compliance and Self-assessment Arising from Profits and Losses on Foreign Exchange Dealings.

And the other:

Towards a Modern Corporate Bankruptcy Regime: The New Law of Bankruptcy in Indonesia.

* A Judge of the Court of Appeal of New Zealand. The author would like to thank Sarah Allen for her invaluable assistance in the preparation of this lecture. 
More as a matter of saying something to break the deafening silence which ensued, I volunteered that I had thought up the last topic that very morning as I had walked past Parliament on the way to the Court. "That's it," said Professor McLauchlan, "the relationship of Parliament and the courts will be fine". Thus, at a stroke, the good professor demonstrated the happy melding of the practical with the academic which has always been a pre-eminent hallmark of this Law School.

I decided to begin my address with not one but two quotations. The first, by Lord John Russell: ${ }^{1}$

Every political Constitution in which different bodies share political power is only enabled to exist by the forbearance of those among whom this power is distributed.

The second comes from Alexander M Bickel: ${ }^{2}$

Judges have, or should have, the leisure, the training, and the insulation to follow the ways of the scholar in pursuing the ends of government. This is crucial in sorting out the enduring values of a society ...

\section{A Parliamentary Sovereignty; Is There any Doubt?}

Ever since the Glorious Revolution of 1688, the question whether the judiciary must acknowledge Parliament's sovereign legislative power without qualification has vexed our attention. A great number of judges have positively affirmed the doctrine of parliamentary supremacy. On the other hand, many academics, ${ }^{3}$ and an increasing number of Judges writing extra-judicially, ${ }^{4}$ have concluded that Parliament's powers are less than omnipotent and that, in extreme circumstances, the validity of legislation can be reviewed by the courts. The debate continues. Lawyers, being lawyers, look for a definitive answer.

1 K J Scott The New Zealand Constitution (Oxford University Press, Oxford, 1962).

2 Alexander M Bickel The Least Dangerous Branch: The Supreme Court at the Bar of Politics (BobbsMerrill, Indianapolis, 1962).

3 In particular, T R S Allan "The Limits of Parliamentary Sovereignty" [1985] PL 614 ["Parliamentary Sovereignty"]; and Philip Allott "The Courts and Parliament: Who Whom?" [1979] CLJ 79.

4 Sir Robin Cooke "Fundamentals" [1988] NZLJ 158 ["Fundamentals"]; Lord Woolf "Droit Public English Style" [1995] PL 57, 67-69 ["Droit Public"]; Sir John Laws "Law and Democracy" [1995] PL 72 ["Law and Democracy"]; Sir Stephen Sedley "Human Rights: a Twenty-First Century Agenda" [1995] PL 386; and Hon E W Thomas "Administrative Law and the Rule of Law" (1987) NZ Law Conf 172, 177, 180 ["Administrative Law"]. 
So, too, did the sturdy Mr Reginald Shaw. Mr Shaw is a New Zealand superannuitant. The Commissioner of Inland Revenue assessed him on his income above a specified exemption from sources other than his superannuation. Mr Shaw did not dispute that the Commissioner had correctly applied the relevant legislation. Rather, he argued that the legislation itself, Part XA of the Income Tax Act 1976, was invalid and, appearing in person, he pursued his argument to the Court of Appeal, seeking a declaration to that effect.

Mr Shaw contended that Magna Carta's prohibition on discriminatory or extraordinary taxation was such a fundamental common law right that Parliament could not legislate to override it. The Court ${ }^{5}$ observed that the legitimacy of each institution depends to no small extent on the respect each pays to the conventions which delimit the respective roles of the legislature, the executive, and the courts. It acknowledged the controversy as to what the courts might do if constitutional conventions were to break down and the courts were faced with hypothetical situations, such as legislation removing the right of citizens to resort to the courts for the determination of their rights.

The Court concluded that Mr Shaw's case was not one where it should enter upon such a far-reaching and critical debate. Adopting the comments of Baragwanath $\mathrm{J}$ in Cooper $v$ Attorney-General, ${ }^{6}$ the Court found itself: ${ }^{7}$

[r]elieved from venturing into what happily remains in New Zealand an extra-judicial debate, which the good sense of parliamentarians and Judges has kept theoretical, as to whether in any circumstances the judiciary could or should seek to impose limits on the exercise of Parliament's legislative authority to remove more fundamental kinds of substantive rights.

As Mr Shaw's case fell short of requiring it to consider revisiting conventions so fundamental to New Zealand's constitutional structure, a unanimous Court declined to express a view on the debate.

In my view, the Court's answer was precisely right. The debate should be left unresolved. An answer should be deferred until such time as the courts are in fact confronted with legislation which raises a fundamental constitutional issue and places in jeopardy the basis of representative government, the rule of law, or the fundamental rights and freedoms which are embedded in these democratic ideals. Much will necessarily

5 Richardson $\mathrm{P}$, and Henry and Blanchard JJ.

6 Cooper v Attorney-General [1996] 3 NZLR 480 [Cooper].

7 Cooper above n 6, 484 . 
depend on the circumstances at that time. Until then, the answer need not be known; it can, as it were, be left up in the constitutional air.

The resulting uncertainty or inconclusiveness serves a valuable constitutional function. A constitution is primarily an instrument to distribute, or the means of distributing, political power ${ }^{8}$ and the uncertainty, to paraphrase the words of Lord Russell quoted above, furthers forbearance among those to whom political power is distributed. Uncertainty as to whether the courts will intervene to strike down legislation perceived to undermine representative government and destroy fundamental rights must act as a brake upon Parliament's conception of its omnipotence; and uncertainty as to the legitimacy of its jurisdiction to invalidate constitutionally aberrant legislation must act as a curb upon judicial usurpation of power. A balance of power between these two arms of government is more effectively achieved by the unresolved doubt attaching to the question than would be the case if the question were to be resolved affirmatively in either Parliament's or the judiciary's favour. The inconclusiveness begets a cautious forbearance, one or the other.

For the purpose of this thesis, therefore, it is unnecessary to do more than postulate the possibility that Parliament's legislative supremacy is not absolute. It is enough that the judiciary at a future date may be moved in exceptional circumstances to intervene and review the validity of legislation which is perceived to be beyond the constitutional pale. ${ }^{9}$ I prefer to rest this possibility, not on a reassertion of distant authority such as Dr Bonham's Case, ${ }^{10}$ but on the perception that it represents a development in a constitution which, although unwritten - or, perhaps, because it is unwritten - remains dynamic and capable of responding to the emerging and changing needs of the modern state. The possibility that

8 Papers and Addresses of Learned Hand, in Irving Dilliard The Spirit of Liberty (3ed, University of Chicago Press, Chicago, 1960) 159.

9 The New Zealand Bill of Rights Act 1990 does not retard this possibility. Section 4 explicitly acknowledges, of course, that the courts do not have the power to strike down legislation which is inconsistent with the fundamental rights expressed in the Act. Parliament's reaffirmation of its legislative supremacy, however, begs the question whether that supremacy is open to challenge in the courts in extreme circumstances. Whether reliance is placed on early authority or the organic development of the constitution, the effect of s 4 stands or falls with the court's response to the particular legislation under challenge. It can be no answer to the question whether Parliament's legislative supremacy is absolute to say that it is absolute because Parliament says it is so. The circuity of the argument is patent.

10 Dr Bonham's Case (1610) 8 Co Rep 113b; 77 ER 638. 
the judiciary may yet assert a power to review extreme legislation is part of an ongoing process of constitutional development. ${ }^{11}$

\section{A RENEWED INTEREST IN REAPPRAISING THE CONSTITUTION}

The needs and perceptions which have stimulated a renewed interest in the possibility that the judiciary may have a greater constitutional role to play than self-perpetuating obeisance to Parliament's will seem to be fourfold.

The first and foremost factor is undoubtedly the contemporary recognition, international in scope, accorded fundamental human rights. Fear that majoritarian governments will erode the rights which serve to protect the individual or the freedoms enjoyed by minority and ethnic groups has generated a quest for an independent adjudicator. ${ }^{12}$ Those seeking that independent adjudication note that issues involving fundamental human rights are constantly arising, and they look for a form of constitutional protection which only an independent judiciary can provide.

The second factor relates to the Treaty of Waitangi. Confrontational views as to the proper legal status of the Treaty continue to simmer within the community. True, the Treaty has been accorded the status akin to a constitutional charter in the Court of Appeal. ${ }^{13}$ It has been described as a "founding document" and a "fundamental constitutional document", 14 but the courts have stopped short of incorporating it in the common law of this country as other countries have incorporated basic constitutional charters in theirs. Magna Carta in the United Kingdom is a prominent example. Even as part of the common law, however, the Treaty would be open to legislative change. The

11 T R S Allan "Parliamentary Sovereignty: Law, Politics, and Revolution" (1997) 113 LQR 443 ["Law, Politics, and Revolution"].

12 Sedley, above n 4, 391.

13 New Zealand Maori Council v Attorney-General [1987] 1 NZLR 641, 655-658 per Cooke P, and 673, 682 per Richardson J. But see Attorney-General v New Zealand Maori Council (No 2) [1991] 2 NZLR 147, 149 per Casey and Hardie Boys JJ. For an excellent article, see Catherine Callaghan "Constitutionalisation of Treaties by the Courts - The Treaty of Waitangi and the Treaty of Rome Compared" (1999) 18 NZULR 334. See also Sir Robin Cooke "Introduction" (1990) 14 NZULR 1; Paul McHugh The Maori Magna Carta: New Zealand Law and the Treaty of Waitangi (Oxford University Press, Auckland, 1991); and Paul McHugh "Constitutional Myths and the Treaty of Waitangi" [1991] NZLJ 316. In 1986 the Royal Commission on the Electoral System took the view that the Treaty marked the beginning of constitutional government in New Zealand and recognised the special position of the Maori people: Report of the Royal Commission on the Electoral System: Towards a Better Democracy (Government Printer, Wellington, 1986) para 3.102.

14 New Zealand Maori Council v Attorney-General [1996] 3 NZLR 140, 184-185. 
question, then, is whether, as a fundamental constitutional document, the rights which the Treaty confers are to be put beyond the reach of Parliament to amend or revoke. It is a question which can only be answered by the courts if and when the modification or destruction of those Treaty rights is contemplated by legislation.

A reappraisal of the status of the Treaty is accompanied by a reconsideration of the essentially British notion of the indivisibility of sovereignty. Hobbesian doctrine has long been implicit in British constitutionalism. Sovereignty is seen as "absolute, territorial, indivisible and unlimitable". ${ }^{15}$ McHugh contrasts this perception with the American vision of sovereignty as "divided, confederative, popular and accountable". ${ }^{16}$ With the primary significance accorded the Treaty in this country's constitution, the peculiarly British concept of sovereignty is increasingly seen as an inappropriate basis by which to secure for Maori the rights guaranteed to them under the Treaty and to order the relationship of the two peoples of this country. The pure representative principle will need adjustment to secure these rights and accommodate this relationship.

By far the most outstanding article written in this area is the chapter contributed by Sian Elias (as she then was). In "The Treaty of Waitangi and Separation of Powers in New Zealand", 17 Elias examines the status of the Treaty against the concepts of the separation of powers and parliamentary sovereignty. The four promises made to Maori and guaranteed by the Treaty are dealt with: the guarantee of existing rights of property; the promise of authority; the promise of equal treatment; the acknowledgement of relativity, that is, that the rights guaranteed are not absolute so that the Treaty itself contains a mechanism for adjustment and reconciliation; and the promise to use the Crown's powers of sovereignty or kawanatanga ceded to accord Maori and their culture a priority which secures rangatiratanga and their distinctiveness within the New Zealand society. Elias observes that this Treaty promise is not performed by ensuring that Maori share in the protections accorded human rights which are available to the rest of the population. Rather, it is a guarantee of the type of special position increasingly recognised in international law as being required to secure the identity and culture of indigenous people.

15 Paul McHugh "Sovereignty this Century - Maori and the Common Law Constitution" (2000) 31 VUWLR 187 ["Sovereignty this Century"].

16 "Sovereignty this Century" above n 15, 192.

17 Sian Elias "The Treaty of Waitangi and Separation of Powers in New Zealand" in B D Gray and R B McClintock (eds) Courts Policy: Checking the Balance (Brookers, Wellington, 1995) 206 ["Treaty and Separation of Powers"]. 
Self-evidently, a right to special status does not strike an immediate accord with the notion of majoritarian rule underlying the precept of parliamentary legislative supremacy. ${ }^{18}$ It emerges from Elias's article, however, that what is transferred under the Treaty is at most territorial sovereignty and that the transfer of that sovereignty was conditioned upon performance of the promises guaranteed in it. Thus, it is arguable that the British doctrine of parliamentary sovereignty has no application to the fundamentals of the New Zealand constitution. It is not a necessary feature of the possession of territorial sovereignty. ${ }^{19}$ Indeed, Elias observes that it is time to recognise that the notion of arbitrary parliamentary sovereignty represents an obsolete and inadequate idea of the New Zealand constitution. ${ }^{20}$ Her conclusion is that the Treaty of Waitangi is part of New Zealand law and it is the duty of the courts to protect the principles which are fundamental to the legal order. If a fundamental principle is breached by legislation, then it is the duty of the judiciary to review the legislation if it cannot be construed in a manner consistent with the fundamental principle otherwise violated. ${ }^{21}$ The growing expression of this view, admittedly seldom if ever articulated in such a well-researched and wellreasoned manner, necessarily generates a renewed interest in re-examining the British concept of sovereignty as being indivisible and absolute and in reassessing the role of Parliament and the courts in providing a constitutional guarantee for the rights and promises contained in the Treaty.

The third factor which has prompted a renewed interest in reappraising the constitution has arisen because of a wider appreciation that major changes in the constitutional framework of our governmental structure can and do occur. In the United Kingdom, the courts have had to cope with the inroad into the doctrine of parliamentary sovereignty brought about by that country's entry into the European Community. ${ }^{22}$ In New Zealand, we have seen a momentous change in the electoral system and composition of Parliament with the adoption of Mixed Member Proportional representation (MMP). It is generally acknowledged that this radical change was endorsed by a majority as a result of disenchantment with politicians rather than Parliament or the electoral system as such.

18 "Treaty and Separation of Powers" above n 17, 208-212.

19 "Treaty and Separation of Powers" above n 17, 222.

20 "Treaty and Separation of Powers" above n 17, 224.

21 "Treaty and Separation of Powers" above n 17, 230.

22 See H W R Wade "Sovereignty - Revolution or Evolution?" (1996) 112 LQR 568; and "Law, Politics, and Revolution" above $\mathrm{n} 11$. 
The question, it is fair to say, is increasingly asked, are representative government and our democratic institutions as stable and secure as we might have thought?

In this respect, the impact of MMP on the composition of the governing majority in Parliament should not be overlooked. Under the first-past-the-post system, one or other of the two major parties generally commanded, and controlled, a majority in the House. Under MMP, the majority supporting the government may be made up of a formal coalition of parties or an informal coalition of political interests represented in Parliament. The coalition is likely to have been achieved after negotiation and compromise with one or more minority parties. As part of that process of negotiation and compromise a policy or proposal appropriated by a minority party may become part of the government's legislative programme, notwithstanding that the policy or proposal commands relatively limited positive support in the electorate. A new dimension has been added to the notion of majoritarian government.

Certainly, this possibility was present under the previous system in that political parties embraced diverse interests, but the likelihood was remote. The risk is significantly increased under MMP. It would be idle to pretend that minority political parties are not critically conscious of the need to pass the threshold level of electoral support to obtain representation in Parliament. They will seek to pursue policies or causes which will give them that support. Designed for a limited constituency, these policies or causes are likely to be extreme, at times, perhaps, appealing to those at the fringes of society. Nevertheless, the resulting vote from ardent adherents may be converted into the necessary level of electoral support to provide a presence in Parliament, and with that presence the opportunity to have the policy or cause converted into a legislative proposal. By negotiation or political dealing, and for reasons of political expediency, a proposal having limited positive support in the electorate may obtain the backing of a majority in the House. $^{23}$

Another possibility arises out of a distinction, recently made by Lord Hoffman, which may have even greater significance in New Zealand under MMP than in the United Kingdom under the first-past-the-post system. Writing extra-judicially, ${ }^{24}$ Lord Hoffman

23 The suggestion that this process will not happen because the party with the major support will not accept any policy or cause which would diminish its own support is only partially comforting. Experience indicates that many extreme policies or causes may enjoy a latent appeal, especially when associated with the attainment or exercise of political power.

24 The Rt Hon Lord Hoffmann "Human Rights in the House of Lords" (1992) 62 MLR 159 ["Human Rights"]. 
drew a distinction between a political consensus, that is, a consensus among the major parties and politicians, and a consensus among the people as a whole. He takes as an example the well-known fact that a considerable majority of the public would favour the reintroduction of the death penalty (as is the case in New Zealand). But he points out that politicians taking a traditional Burkean view of their role as representatives and not delegates have ensured and are likely to continue to ensure that this will not happen. ${ }^{25}$ They are able to do so because of the strength and discipline of the party system in the United Kingdom, which means that most voters are forced to buy the complete package of one or other of the three major parties, and politicians gain no advantage by advocating views which may have popular support but which are unacceptable to the leadership of their parties. The result, Lord Hoffmann asserts, is that no one can cast an effective vote in favour of the reintroduction of capital punishment.

This reassurance, either in respect of capital punishment or any other unenlightened cause, cannot now be said to be secure in this country. Party discipline may or may not continue to be strong within the major parties, but when a major party may be dependent on minor parties to form or sustain a government, the views of the leadership of that party are likely to be sufficiently malleable to accommodate views which were previously unacceptable.

Finally, I would add to the factors which point to the possibility of a reappraisal of the concept of parliamentary supremacy, the evolving basis of judicial review. The principle of ultra vires has long served administrative law well. Under the guise of giving effect to Parliament's will, executive action has been declared illegal, irrational and unfair. Parliament, it is held, could not have intended that the governmental agencies it has created and vested with enormous power over citizens should act unreasonably or unfairly. But it has been increasingly recognised that the ultra vires principle is a convenient rationalisation. It cannot explain all instances of judicial intervention and, at times, certainly serves to allow the judiciary to conceal the real justification for developments in judicial review. ${ }^{26}$ Hence, a school of thought has developed which would sever administrative law from its ultra vires roots and recognise that judicial review is a creation of the common law.

25 "Human Rights" above n 24, 160.

26 Paul Craig "Ultra Vires and the Foundations of Judicial Review" [1998] CLJ 63 ["Ultra Vires"]. See also Dawn Oliver "Is the Ultra Vires Rule the Basis of Judicial Review?" [1987] PL 543; Sir John Laws "Illegality: The Problem of Jurisdiction" in Goudie and Supperstone (eds) Judicial Review (2nd ed, Butterworths, London, 1997) Chap 4; and Lord Steyn The Constitutionalisation of Public Law (Constitution Unit, University College, London, 1999). 
Some years ago I broached the thought that the administrator's duty to act rationally and fairly should be regarded as a substantive principle of the common law and not merely an adjunct of statutory interpretation. ${ }^{27}$ Determining whether or not an administrator's actions are irrational because they have been inconsistent in arriving at their decision, or unfair because they have breached an earlier expectation, does not require the introduction of the doctrine of ultra vires. The rule of law requiring decisionmakers to act rationally and to adopt a fair procedure can be applied directly to their actions without, at times, the strained and artificial application of the ultra vires principle. Administrative law principles would then develop, as with any common law principles, other than as an appendage of an Act of Parliament. They would become substantive principles of the common law owing neither their content nor their authority to the legislature. ${ }^{28}$

This viewpoint has much wider and growing support today. ${ }^{29}$ But it is a view which has implications for the relationship of Parliament and the courts. Once judicial review is divorced from the idea of effectuating the intent of the legislature and proceeds as an independent principle of the common law, it has the potential to redirect constitutional thinking. No longer tied to the fiction of doing Parliament's will, judicial review will stand outside Parliament's will. Whether intended or not, the basis will have been laid for a reevaluation of the concept of Parliament's legislative supremacy.

None of these factors, as I have indicated, necessitate more than a reappraisal of the prevalent conviction that Parliament's legislative supremacy is unlimited and illimitable. None require an immediate answer. Each can be mollified by the deferred possibility that the courts may at a future date respond to legislation undermining or destroying the basis of representative government, or the rule of law, or fundamental human rights with an opinion declaring the legislation to be unconstitutional.

Credence can be given to this possibility by postulating a constitutional regime which reasserts the ultimate sovereignty of the people and perceives both Parliament and the courts as the organs of the state to give effect to and protect the people's sovereign power. Save for a small but vital cluster of principles and rights which the courts may hold

\footnotetext{
"Administrative Law" above n 4, 177.

8 "Law and Democracy" above n 4, 78-80.

29 "Ultra Vires" above n 26; and see Mark Elliott "The Demise of Parliamentary Sovereignty? The Implications for Justifying Judicial Review" (1999) 115 LQR 119. For judicial recognition of the courts' constitutional function to determine the law, see the majority judgment in Peters $v$ Davison [1999] 2 NZLR 164 (CA).
} 
Parliament cannot impugn or abrogate, Parliament's legislative authority would in practice continue to remain supreme. ${ }^{30}$ The courts would allow Parliament a wide "margin of appreciation" 31 contemplating the possibility of judicial intervention only where the legislative infringement is patent. Pragmatically speaking, Parliament's legislative supremacy would hold sway. ${ }^{32}$

\section{A The Challenge to Parliament's Legislative Sovereignty}

Parliament's legislative sovereignty has been described as the ultimate principle of our constitution. It is at one and the same time a political fact, a product of the political history of the United Kingdom and this country, a convention of the constitution and a fundamental principle of the common law. ${ }^{33}$ Yet, the relationship between Parliament and the judiciary is perceived to be simple and straight-forward. Parliament asserts sovereign legislative power and the courts acknowledge its omnipotence. ${ }^{34}$ There are no exceptions to this omnipotence other than those inherent in the concept itself; a present Parliament cannot bind future Parliaments or, as I would prefer to put it, a future Parliament exerting its legislative sovereignty will not permit itself to be bound by a past Parliament. The courts are bound to obey any statute Parliament passes. ${ }^{35}$ Nor will they hold an Act of Parliament invalid. Short of an unlikely revolution, Parliament's legislative sovereignty cannot be unseated from its constitutional throne.

30 For a comprehensive article, see Mathew Conaglen "Judicial Supremacy: An Alternative Constitutional Theory" (1994) 7 AULR 665 ["Judicial Supremacy"].

31 The Observer and the Guardian v United Kingdom (1991) 14 EHRR 153, 178 (ECHR). The phrase appears to have originated in Sunday Times $v$ United Kingdom (1979) 58 Int L Reps 491, 529-537 (European Court of Human Rights). It has been used by the Supreme Court of Canada, in for example Irwin Toy $v$ Que [1989] 1 SCR 927, 999. For illustrations of the concept in the Supreme Court, see $R v$ Edwards Books \& Art [1986] 2 SCR 713; $R v$ Whyte [1988] 2 SCR 3; Canadian Newspapers Co v AG of Canada [1988] 2 SCR 122; British Columbia Government Employees' Union v AG of British Columbia [1988] 2 SCR 214; United States $v$ Catroni [1989] 1 SCR 1469; and Prostitution Reference (Re ss 193 and 195.1 of Criminal Code) [1990] 2 SCR 1123. See also Peter Hogg Constitutional Law of Canada (3 ed, Casswell, Ontario, 1992) 878-882.

32 "Judicial Supremacy" above n 30, 672.

33 See Philip A Joseph Constitutional and Administrative Law in New Zealand (Law Book Company Limited, Sydney, 1993) 418 [Constitutional and Administrative Law].

34 Lord Steyn "The Weakest and Least Dangerous Department of Government" [1997] PL 84, 85 ["Weakest and Least Dangerous"]. For an entrenched defence, see Hon Michael Kirby "Lord Cooke and Fundamental Rights" (1998) 24 Commonwealth Law Bulletin 496.

35 Lee v Bude and Torrington Railway Co (1871) LR 6 CP 576, 582 [Torrington Railway]. 
Framed in this way, Parliament can by legislation override the core elements of representative government, the basic tenets of the rule of law, and fundamental human rights. Such a prospect might seem alarming.

One response to this alarm is purely pragmatic. These things, it is thought, will never occur. They are so improbable as to spurn serious consideration. The best safeguard against such aberrant legislation, it is said, is the "good sense of the people" and the mobilisation of public opinion. ${ }^{36}$ No one can deny this democratic verity. But it is a political rather than a constitutional safeguard. It does not necessarily protect the body politic against a popular departure from the essential basis of representative government. It does not mean that the rule of law, which has never been closely defined in the public mind, cannot be turned upon itself for a temporary gain to the general populus. Nor does it mean that a transient or indifferent majority may not seek to repress an individual's or group's fundamental human rights. Experience has confirmed the difficulty of drawing the line between what is or is not a legitimate interference with fundamental rights in a democratic society. ${ }^{37}$ For the protection of these basic democratic properties the ultimate safeguard can only be the independent adjudication which the judiciary offers.

Moreover, as Sir William Wade has observed, all writers on sovereignty are bound to deal in improbable examples, and the improbable case will often throw light on the actual. ${ }^{38}$ Nor can we be confident that the improbable will never occur when the Cabinet heads the executive branch of government and Parliament is dominated by the majority in the House. Regard must also be had to the lessons of history where the seemingly unthinkable has from time to time occurred. In all, we cannot be wholly confident that today's improbability may not be tomorrow's crisis.

If representative government, the rule of law, and fundamental rights are to be constitutionally protected, however, something less than a crisis must be contemplated. The situation in which the courts might consider intervening is unlikely to amount to a confrontation. Revolution, as such, is a distant prospect. In the more likely but less dramatic circumstances which may eventuate, the value of the judiciary's response to constitutionally dubious legislation is its capacity to mobilise public opinion. Because the individual citizen is dwarfed by the state, and because the legislature may be relatively subservient to the executive, the judiciary represents the most immediately available and

36 Liversidge v Anderson (1942) AC 206, 260-61 per Lord Wright [Liversidge].

37 See Ministry of Transport $v$ Noort [1992] 3 NZLR 260; Temese $v$ Police (1992) 9 CRNZ 425; and B $v$ Director-General of Social Welfare [1996] 2 NZLR 134

H W R Wade "The Basis of Legal Sovereignty" [1955] CLJ 172, 173 ["Legal Sovereignty"]. 
authoritative resource to discern and publicly proclaim the unconstitutionality of legislative action. ${ }^{39}$

With the high reputation he enjoys as an administrative lawyer, it is, perhaps, not surprising that Lord Woolf has been the most recent protagonist of the view that Parliament's supremacy is not absolute. ${ }^{40}$ The distinguished Master of the Rolls posed the question; what would happen if a party with a large majority in Parliament used that majority to abolish the courts' entire power of judicial review in express terms? Judicial review, Lord Woolf pointed out, is in origin as ancient as the common law and predates our present form of democracy. Founding his thinking on the rule of law, the Master of the Rolls concluded that ultimately there are limits on the supremacy of Parliament which it is the court's undeniable responsibility to identify and uphold. ${ }^{41}$ These limits are, he concluded, limits of modest dimensions which any democratic citizen would accept. They are no more than necessary to enable the rule of law to be preserved.

Lord Woolf acknowledged that his approach was a "shadow reflection" of the trail blazed by Lord Cooke. ${ }^{42}$ A "doubt" that Parliament's competence was limited in $1979^{43}$

39 A formula which has the potential to enable the judiciary to mobilise public opinion but which, in deference to the theory of parliamentary legislative supremacy, does not involve the court striking down legislation is s 4(2) of the Human Rights Act 1998 (UK). Under this provision the courts may declare legislation to be incompatible with the European Convention. It is difficult not to accept, however, that a declaration by the courts that legislation is incompatible will have a marked impact on public opinion and lead to insistent political pressure to have the legislation conform with the judiciary's perception of the requirements of the Convention. Reference also may be made to $\mathrm{s} 33$ of the Canadian Charter of Rights and Freedoms. Resort to what is called "the s 33 override" promotes a healthy dialogue between the legislature and the courts. See Hon Ian Binnie, "Equality Rights in Canada: Judicial Usurpation or Missed Opportunities?" Legal Research Foundation Conference, Liberty, Equality, Community: Constitutional Rights in Conflict? (1999) 25, quoting Peter Hogg in "The Charter Dialogue Between Courts and Legislatures" (1997) 35 Osgoode Hall LJ 75, 79-80:

Where a judicial decision is open to legislative reversal, modification, or avoidance, then it is meaningful to regard the relationship between the Court and the competent legislative body as a dialogue. In that case, the judicial decision causes a public debate in which Charter values play a more prominent role than they would if there had been no judicial decision. The legislative body is in a position to devise a response that is properly respectful of the Charter values that have been identified by the Court, but which accomplishes the social or economic objectives that the judicial decision has impeded.

"Droit Public" above n 4, 67.

41 "Droit Public" above n 4, 69.

42 "Droit Public" above n 4, 68. 
became a "reservation" in $1982^{44}$ and a presumption in $1984 .{ }^{45}$ Writing extra-judicially four years later, ${ }^{46}$ Lord Cooke argued that the constitution is built on two unalterable pillars; a democratically elected legislature which enacts the laws, and an independent judiciary which interprets them. Yet, implicit in a free democracy are certain rights which, because they are fundamental to the constitution, are inviolable. That inviolability is to be protected by the courts. ${ }^{47}$

According to this school of thought, Parliament has never enjoyed sovereign legislative power. The theory asserts the supremacy of fundamental law over statute law, an attitude dating back to Coke CJ's notorious dictum in Dr Bonham's Case in $1610^{48}$ to the effect that when an Act of Parliament is against common right or reason, or repugnant, or impossible to be performed, the common law will control it and adjudge the Act to be void. Coke CJ was not alone. Sir Henry Hobart CJ approved the dicta in two cases in the same decade; ${ }^{49}$ it was supported by Vaughan CJ in the seventeenth century; 50 and endorsed by Lord Holt $\mathrm{CJ}$ in the early part of the eighteenth century. ${ }^{51}$ But it must be acknowledged that these dicta have been overwhelmed by the weight of subsequent judicial practice and repeated authority disavowing anything other than a subservient role for the judiciary. Willes $\mathrm{J}$ in 1871, for example, in his much-quoted refutation of Coke's dictum, proclaimed that it

$43 \quad L v M[1979] 2$ NZLR 519, 527.

44 New Zealand Drivers' Association v New Zealand Road Carriers [1982] 1 NZLR 374, 390.

45 Taylor v New Zealand Poultry Board [1984] 1 NZLR 394, 398. Lord Cooke's dicta in this and the earlier cases are to be seen in context. Huscroft and Rishworth in Rights and Freedoms (Brookers, Wellington, 1995) 10 have pointed out that a series of events between 1975 and 1984 contributed to a view in some quarters that the government of the day led by the then Prime Minister, the Rt Hon Mr R D Muldoon, was prepared to act, and did act, in a manner which was unconstitutional. These events are traced by the authors who suggest that they were the direct catalyst for the bill of rights movement. Similarly, the perception that the government under Mr Muldoon was prepared to act and did act in a manner which was unconstitutional may not have been irrelevant to Lord Cooke's warning dicta.

46 "Fundamentals" above n 4, 163-164.

47 "Fundamentals" above n 4, 163-164. For the contribution of Murphy J in Australia, see Constitutional and Administrative Law above n 33, 443-444, and "Judicial Supremacy" above n 30, 681-682.

48 Dr Bonham's Case above n 10.

49 Day v Savadge (1615) Hob 85; 80 ER 235; Lord Sheffield v Ratcliffe (1615) Hob 334; 80 ER 475.

50 Thomas $v$ Sorrell (1674) Vaughan 330; 124 ER 1098.

51 City of London $v$ Wood (1701) 12 Mod 669; 88 ER 1592. 
stands as a warning rather than an authority to be followed. ${ }^{52}$ Even the expression of a judicial warning, however, would seem to presuppose that the capacity to act in defiance of Parliament has not been forever foreclosed. Otherwise it is a somewhat empty warning.

Underlying the view that the judiciary may question the validity of an Act of Parliament is a proposition owing more to logic than judicial recognition. Wade has pointed out that the rule of judicial obedience to statute is in one sense a rule of the common law, but in another sense - which applies to no other rule of common law - it is the ultimate political fact upon which the whole system of legislation hangs. Legislation owes its authority to the rule: the rule does not owe its authority to legislation. To say that Parliament can change the rule, merely because it can change any other rule, is to put the cart before the horse. ${ }^{53}$ In short, the practice of judicial obedience to statute cannot itself be based upon the authority of statute. The rule must be logically prior to any Act of Parliament.

In my thinking, however, the idea that Parliament has not enjoyed complete legislative supremacy is ruled out simply because the doctrine has been endorsed so often by the courts. It would require a traumatic departure from established legal methodology to resurrect the authority of $\mathrm{Dr}$ Bonham's Case. Indeed, a recent ringing rebuttal of the notion that Parliament is anything other than supreme has been asserted by Lord Irvine. ${ }^{54}$ The now Lord Chancellor describes extra-judicial claims of a right to review the validity of an Act of Parliament as "judicial supremacism". To him, the suggestion is contrary to the established laws and constitution of the United Kingdom, and has been since 1688. ${ }^{55} \mathrm{He}$ cites judicial statements of the highest authority in support. ${ }^{56}$ If ever there were an assault upon the basic tenets of democracy he suggests, 57 it is an exercise in "judicial romanticism" to believe that judicial decisions could hold back what would, in substance, be a revolution. Lord Irvine does allow, however, that if such a revolutionary tide in our affairs were ever to come about, it would be for the judges of that time, and not of today, to

52 Torrington Railway above n 35, 582.

53 "Legal Sovereignty" above n 38, 187-188; "Parliamentary Sovereignty" above n 3, 621 and "Law and Democracy" above $n 4,86$.

54 Lord Irvine of Lairg, QC "Judges and Decision-Makers: The Theory and Practice of Wednesbury Review" [1996] PL 59, 75-78 ["Judges"]; and see "Weakest and Least Dangerous" above n 34.

55 "Judges" above n 54, 76.

56 Liversidge above n 36, 260-261 per Lord Wright; and Madzimbamuto v Lardner Burke [1969] 1 AC 645-723, per Lord Reid.

57 "Judges" above n 54, 77. 
decide how they should properly respond. ${ }^{58}$ But, again, this seems to leave the possibility of future intervention open.

\section{TOWARDS A CONTEMPORARY CONSTITUTION}

A new stream of thought is emerging which would also deny absolute and unqualified legislative sovereignty to Parliament. This challenge is portrayed as part of the ongoing development of our unwritten constitution. Just as a written constitution is regarded as a "living" document which can be interpreted and reinterpreted so as to be relevant to the times, so too an unwritten constitution must have the fluidity to permit it to be defined and redefined to meet the developments and demands of each generation.

The more recent challenges to the doctrine of parliamentary supremacy have been most convincingly advanced in the extra-judicial writings of Sir John Laws and Sir Stephen Sedley of the United Kingdom. Sir John Laws begins with the role of the courts in judicial review, which he believes is developing to offer an explicit and systematic protection of constitutional rights. Recognising that there are established constitutional norms, some of considerable antiquity, Laws regards the absence of what he calls a sovereign text as meaning that the legal distribution of public power consists ultimately in a dynamic settlement, acceptable to the people, between the different arms of government. That dynamic settlement can change, as history in the last 300 years shows it can, without revolution. Thus, Laws expresses the opinion that the survival and flourishing of a democracy in which basic rights are not only respected but enshrined requires that those who exercise democratic political power must have limits set to what they may do; limits which they are not allowed to overstep. If this is right, he states, it is a function of democratic power itself that it be not absolute. ${ }^{59}$

Baulking at what he believes to be an outdated, or perhaps misunderstood, notion of the sovereignty of Parliament, ${ }^{60}$ Laws asserts a higher-order law by virtue of which fundamental rights possess a status which no government with the necessary majority in Parliament has the right to destroy. ${ }^{61}$ For it to be otherwise would mean that the right is not a guaranteed right but exists, in point of law, at least, only because the government chooses to let it exist. If such absolute power is beyond the reach or curtailment of review, fundamental rights are only privileges, and the fact Parliament is an elected body cannot

58 "Judges" above n 54, 77.

59 "Law and Democracy" above n 4, 81.

60 "Law and Democracy" above n 4, 82.

61 "Law and Democracy" above n 4, 84-90. 
immunise it from playing the tyrant's role. ${ }^{62}$ Laws proceeds to extend this perception to democracy itself. It is, he says, a condition of democracy's preservation that the power of a democratically elected government - or Parliament - be not absolute. ${ }^{63}$ Ultimate sovereignty therefore rests not with those who wield governmental power, but in the conditions under which they are permitted to do so. The constitution, not the Parliament, is in this sense sovereign. ${ }^{64}$ Laws' writing exhibits a healthy recognition of the reality that legislative power rests with the majority in Parliament and not Parliament the institution. Parliament is the constitutional vehicle for the legislative process.

Laws' contemporary, Sir Stephen Sedley perceives in the reassertion of judicial oversight of government, which he rightly describes as having been the great achievement of the common law in the 1970s and 1980s, a move to fill lacunae of legitimacy in the functioning of democratic politics. A "judicial refashioning" has occurred within the organic constitution with popular support sufficient to mute political opposition to it. Still emerging, he argues, is a new constitutional paradigm, no longer of Dicey's supreme Parliament to whose will the rule of law must finally bend, but one of "a bi-polar sovereignty of the Crown in Parliament and the Crown in its courts, to each of which the Crown's ministers are answerable - politically to Parliament, legally to the courts".65 Predicated on the primacy of democracy as a basis for assuming such a jurisdiction, Sedley articulates the problem in these terms: "... how to ensure that as a society we are governed within a law which has internalised the notion of fundamental human rights." 66 The rule of law is also adopted, if necessary, as a higher-order principle ${ }^{67}$ which, like democracy, is accorded primacy - without the need of a leap of faith - by the social consensus which exists around those concepts. "If in our society," the distinguished jurist states, "the rule of law is to mean much, it must at least mean that it is the obligation of the courts to articulate and uphold the ground rules of ethical social existence which we dignify as fundamental human rights, temporary and local though they are in the grand scheme of things." 68

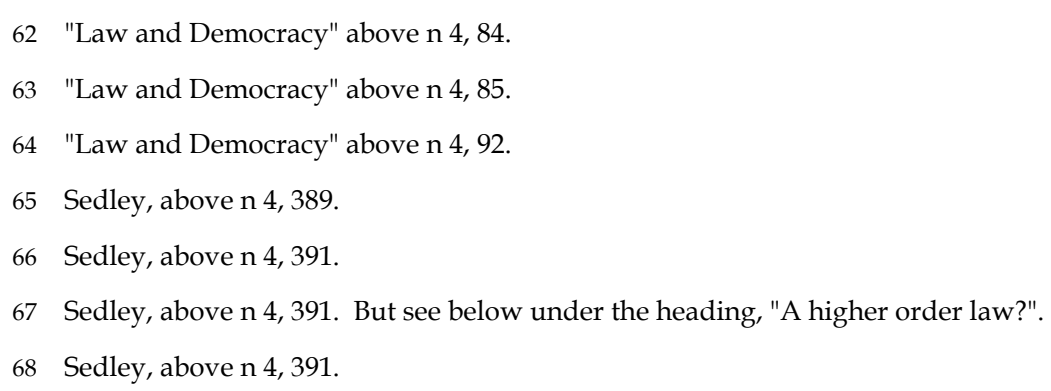




\section{THE SOVEREIGNTY OF THE PEOPLE}

It is not only to Lord Irvine that such theories will sound like a plea for judicial supremacism. ${ }^{69}$ The supremacy of Parliament, it will be asserted, becomes in the last resort the supremacy of the judiciary. An emphatic insistence, such as that pressed by Laws, ${ }^{70}$ on the vital necessity of democratic institutions of government and the imperative of fundamental rights does not meet this assertion. Rather, I suggest, it is preferable to say that in a democracy in which it is the people who are sovereign, the language of supremacism or supremacy is unnecessary to describe the respective functions of Parliament and the courts in the democratic service of the people. Let me elaborate what I mean.

The phrase "parliamentary sovereignty", as such, is a misnomer. ${ }^{71}$ In a full and free democracy, sovereignty rests with the people. The constitutional settlement of the seventeenth century established the supremacy of Parliament over the King - of the legislature over the executive. But the shift in power represented a victory for the people. The legislative supremacy of Parliament cannot, in itself, confer sovereignty on that body. Parliament must look to the people for the source of its power. Even Dicey, notwithstanding his insistence on distinguishing legal from political sovereignty, provides support for this view; he states "... the essence of representative government is that the legislature should represent or give effect to the will of the political sovereign, ie of the electoral body, or the nation". ${ }^{72}$ But with due respect to Dicey, it is this concept, the sovereignty of the people, and not Parliament's legislative supremacy, which is the fundamental plank of our constitution.

Unable to undertake the machinery of government, the people have delegated that task together with such powers as are necessary to carry it out to their elected representatives. But the elective government must remain answerable for the exercise of its delegated powers. In this way the government in Parliament can be perceived as the agent of the people exercising the powers of government which have been devolved to it by the

69 The phrase is attributed to Sedley; "Law and Democracy" above n 4, 85.

70 "Law and Democracy" above n 4, 85.

71 See E C S Wade and A W Bradley, Constitutional and Administrative Law (Longman, London, 1985) 64-66 and 69-70.

72 "Parliamentary Sovereignty" above n 3, 622. See also Rodney Brazier "The Non-Legal Constitution: Thoughts on Convention, Practice and Principle" (1992) 43 NILQ 262, 265 ["NonLegal Constitution"]. 
people. ${ }^{73}$ Nothing in this concept of popular sovereignty suggests that the people have delegated to government - or to Parliament - the power to destroy the machinery by which they exert their ultimate sovereignty. Consequently, once it is accepted that the sovereignty of the people is the fundamental plank of the constitution and that this sovereignty cannot be served other than through representative government, it is absurd to suggest that the plenary power delegated to Parliament by the people embraces the power to destroy representative government.

When the relationship of Parliament to the people is described in these terms, it can be clearly seen that Parliament's legislative supremacy is necessarily limited by the nature and terms of this delegation or political "trust". Parliament's legislative supremacy, in other words, is limited by its essential constitutional function. If Parliament should cease to be a representative assembly in any plausible sense, or if it proceeded to enact legislation undermining the democratic basis on which it exercises the sovereign power of the people, there is nothing in the notion of Parliament's omnipotence which would preclude judicial resistance rather than obedience. ${ }^{74}$ A statute, for example, which deprived a section of the adult population of the right to vote could not be applied in the courts as law without the courts disregarding the basic premise on which Parliament's legislative supremacy is based; the sovereignty of the people and its practical imperative, representative government.

In conventional constitutional theory, the sovereignty of the people is protected by political conventions. A distinction is drawn, traceable to Dicey, between conventions and the law proper. Although conventions are intended to regulate the conduct and relationship of all three branches of government and are regarded as obligatory, it is said that they are not in reality laws since they are not enforced by the courts. ${ }^{75}$ If conventions cannot be enforced in the courts, a convention to the effect that Parliament not exercise its legislative sovereignty so as to destroy the basis of representative government amounts to no more than a requirement that Parliament apply constitutional limits to itself. The sanction is no more than the force of public opinion. But the constitutional edifice that has been erected around political conventions cannot as a matter of law preclude the courts from intervening should they choose to do so. The courts may simply decline to accept the force of a convention, just as they may decline to accept the omnipotence of parliamentary

73 Hon E W Thomas "Secrecy and Open Government" in Essays on Law and Government (Law Book Co Ltd, 1995) Vol 1, 182, 191-192.

74 "Parliamentary Sovereignty" above n 3, 621.

75 "Non-Legal Constitution" above n 72, 264-267. 
legislative supremacy when confronted with extreme legislation. It is more likely, however, that the courts may decide to recognise and give effect to a convention. Conventions are, in other words, capable of being recognised and given the force of law. They neither add to nor detract from the strength of parliamentary legislative supremacy as against the possibility of judicial review of the validity of legislation.

The debate whether conventions may harden into justiciable law is far from resolved, notwithstanding some cases to the contrary. ${ }^{76}$ In so far as conventions reflect the relationship or balance between the organs of government, the likelihood that one or other of them may crystallise into law is ever-present. Indeed, there may be no other means by which the courts could resolve a dispute. But, once it is accepted that the courts may recognise and give a convention the force of law, what is to stop the courts from doing just that in respect of the most obvious and undisputed convention of all, that is, that Parliament must not use its sovereign legislative power in a tyrannical or oppressive way?

An important qualification is at once required to confirm that the sovereignty of the people may need to be augmented by the support and, if necessary, resistance of an independent judiciary. The qualification is that the concept is not to be equated with the notion of majority rule. It has been widely recognised that the tyranny of the majority may be no less oppressive than the tyranny of a despot. ${ }^{77}$ Underlying the majoritarian principle, therefore, must be a recognition of the fact that majorities may be transient, may not be fully and freely informed, and may not be committed to the very democratic precepts which the majority invoke to exercise the power they hold. To the extent that any particular majority contrives to enact oppressive legislation, that majority simultaneously

76 For discussion, see Reference Re Amendment of the Constitution of Canada (1981) 125 DLR (3d) 1; Manuel v AG [1982] 3 All ER 822 (CA); AG v Jonathan Cape Ltd [1976] QB 752; and Re Resolution to Amend the Constitution [1981] 1 SCR 753. See also Sir Robin Cooke "Making the Angels Weep" [1994] NZLJ 361; and Constitutional and Admnistrative Law above n 33, 263-265.

77 Professor Unger has said that one of the "dirty little secrets of contemporary jurisprudence" is "its discomfort with democracy". Evidence of this discomfort is to be found in large part in the ceaseless identification of restraints upon majority rule as the overriding responsibility of judges and jurists. (Roberto Mangabeira Unger What Should Legal Analysis Become? (Verso, London, 1996) 72-73, 115.) Professor Waldron provides an interesting commentary on this view, including the perception that there is nothing tyrannical in the prevalence of majority opinion in itself, providing that the resulting decision is reached in good faith and in a public-spirited way. (Jeremy Waldron, Law and Disagreement (Clarendon Press, Oxford, 1999) 8-14. [Law and Disagreement]) Whether I suffer from Professor Unger's "dirty little secret" or not, realism pushes me to the conclusion that democracy can be imperfect. Indeed, it would seem a safe assumption to say that, having regard to the foibles and self-interest of human-beings, democracy can only ever aspire to perfection. Good faith and public-spiritedness are very insecure predicates. 
strikes at the legitimate basis of its own exercise of power. Its sway in Parliament is necessarily subject to the same limitations as Parliament itself if the ultimate sovereignty of the people is to be recognised through truly representative government. The constitutional predicate of the sovereignty of the people thus contains within itself a constitutional canon that gives force to enduring democratic values which may at any particular time be at variance with the wishes of a transient, ill-informed, or indifferent majority.

\section{A HIGHER ORDER LAW?}

Proponents of the view that Parliament's legislative supremacy is not absolute have asserted a higher order law. It is by virtue of such a concept that Sir John Laws holds that no government with a majority can subvert fundamental rights. ${ }^{78}$ Similarly, Sir Stephen Sedley earlier suggested that the rule of law can be adopted, if necessary, as a higher order principle which, like democracy, is accorded primacy by the social consensus which exists around those concepts. ${ }^{79}$ Sedley clarified his meaning in the first of his outstanding Hamlyn Lectures. ${ }^{80}$ In the end, the learned author suggested, we have to come back to a society's consensus about what is on and what is off limits. He considered that this is not best described as a higher order law because it has no authoritative source and no forum or means of enforcement. "It is rather", he continued, "what we collectively accept as the limit of what is tolerable". ${ }^{81}$

I agree that there is little value in postulating a higher order law, if only because of its undertones of natural law theory. Such theory is best left to legal historians and reflective philosophers. Neither the core elements of representative government nor the rule of law are to be found in the heavens. The same must be said for fundamental human rights. Notwithstanding Professor Dworkin's fluency, rights are not "trumps". ${ }^{82}$ Rights cannot, as Professor Waldron states, be dealt with on a different plain in law far from the hurly burly of legislators and political controversy. ${ }^{83}$ As with the central tenets of representative government, they obtain command by virtue of their widespread acceptance in the

78 "Law and Democracy" above n 4, 81.

79 Sedley, above n 4, 389.

80 The Hamlyn Lectures: Freedom, Law and Justice, by the Rt Hon Lord Justice Sedley "The Free Individual and the Free Society", 10 [Hamlyn Lectures].

81 Hamlyn Lectures above $\mathrm{n} 80,10$.

82 Ronald Dworkin Taking Rights Seriously (Harvard University Press, Cambridge, 1997).

83 Law and Disagreement above n 77, 12. 
abstract. This widespread acceptance in abstract form is given the appearance of universality by virtue of the proclamation of basic rights in international charters. Human rights are better perceived as prerequisites to the rule of law ${ }^{84}$ and, as such, part of the constitutional fabric which underpins the working of democracy.

No higher order law is necessary, therefore, to justify the court's ability to intervene any more than a higher order law is necessary for the opposite proposition, that is, that Parliament's legislative omnipotence is supreme. Both propositions are a method of ordering the constitution and are grounded in a political fact, judicial preparedness to recognise the force of enactments of Parliament. ${ }^{85}$ While the courts may intervene or not depending on the perception of the consensus which exists as to what is or is not tolerable, however, that is not the source of the court's capacity to intervene. The source of that capacity is the unwritten constitution which has enshrined the sovereignty of the people. In this respect, the position is exactly as it would be if the constitution had been accepted at a point in history and reduced to writing. Written or not, the constitution prescribes representative government, the rule of law and the protection of basic rights. As such it may be perceived as fundamental to our law but not a higher order law.

To rest the authority for the courts' power to review Acts of Parliament on what the community accepts at any given time is the limit of what is tolerable is to risk subjecting core requirements of representative government, the basic tenets of the rule of law and fundamental rights to the shifts and shafts of public opinion. Majority opinion may all too readily be perceived as a consensus. Such a basis lacks the enduring quality required for the constitutional ordering of a democracy. It must be conceded, however, that in a democracy the justification for the court's intervention will ultimately be assessed by the people. The preservation of representative government will ensure that. But the ultimate judgment of the people is a factor which is common to democracies served by both unwritten and written constitutions. It is in this sense, not so much as a consensus for what the courts may choose to do, but as an ultimate acceptance of what they have done that the court's intervention will be perceived to have been either justified or an objectionable usurpation of judicial power.

It is to avoid the latter opprobrium that the judiciary must not only be restrained in its approach but also be conscious of the need through the power of reasoned expression to influence public opinion. Referring to the core rights and purpose of representative government, the enduring qualities of the rule of law and the basic importance of

84 Philip A Joseph "Constitutional Review Now" [1998] NZLR 85, 90.

85 See below Part VI, "A decision for the courts". 
fundamental rights will achieve that objective. Resorting to a so-called higher order law will not have the same effect.

\section{A DECISION FOR THE COURTS}

The decision whether or not the courts should intervene to review oppressive legislation is a decision for the courts. It cannot be otherwise. As the great jurist, Sir John Salmond, pointed out, parliamentary sovereignty is the law "because it is the law, and for no other reason that it is possible for the law itself to take notice of". 86 Wade has observed of Salmond's "ultimate legal principle" that it is a rule which "lies in the keeping of the courts, and no Act of Parliament can take it from them". "This is another way of saying", he said: 87

that it is always for the courts, in the last resort, to say what is a valid Act of Parliament; and the decision of this question is not determined by any rule of law which can be laid down or altered by any authority outside the courts". "It is", Wade concludes, "simply a political fact".

Professor Allan has agreed that it is right to emphasise the ultimate dependence of fundamental constitutional rules on judicial decision. "Statutes", he points out, "owe their legal force, in the final analysis, to judicial recognition". ${ }^{88}$

Reduced to its minimum, therefore, Parliament's legislative supremacy exists to the extent that the courts give it recognition. The conferral of that recognition is in the nature of a self-denying judicial ordinance. There are, of course, many such self-denying ordinances. The courts already decide, for example, at what point the legislative process should enjoy immunity from judicial scrutiny; whether or not a restrictive rule of interpretation should be applied in construing Parliament's intent; whether to presume a parliamentary intent when in fact the legislature has not addressed the point in issue; and whether a change or development in the law that is proposed in a particular case should be left to Parliament. Although plainly more radical, the decision whether to accord Parliament omnipotence when confronted by oppressive legislation is necessarily a question for the judiciary. No "law" can be stated in advance with sufficient impregnability as to deny the courts the capacity to determine at a future date what will or will not be recognised as the law.

86 Salmond Jurisprudence (11 ed, Sweet \& Maxwell, London, 1953) 137.

87 "Legal Sovereignty" above n 38, 172.

88 "Law, Politics, and Revolution" above n 11, 443-444. 
Recognising that the decision is inevitably one for the courts renders Parliament's legislative supremacy dependent on the exercise of judicial restraint. Many lawyers and lay persons alike are unwilling to acknowledge that this is the reality. They are reluctant to accept that in the last resort a principle, which has been perceived to be the fundamental plank of our unwritten constitution since sovereign power was wrested from the King in the Glorious Revolution, should rest upon the restraint - or lack of restraint - of an unelected judiciary.

At once it must be admitted that the courts have already declined to exercise that restraint. They declined to do so in the most celebrated of all administrative law cases, Anisminic $v$ Foreign Compensation Commission. ${ }^{89}$ Can anyone seriously doubt that s 4(4) of the Foreign Compensation Act 1950 (UK) which provided that decisions of the Foreign Compensation Commission "shall not be called in question in any court of law" was intended to exclude any challenge to that body's decisions in the courts? As a matter of giving effect to Parliament's intention, and in deference to the principle of parliamentary supremacy, the answer would seem perfectly clear. Parliament excluded judicial review. But while the House of Lords would have none of it, their Lordships did not openly defy Parliament. To enable the decision to be reviewed they applied - or rather strained - a rule of construction so as to camouflage the judicial disobedience involved. Is it not time to discard the fiction that Anisminic was resolved by the application of ordinary legal analysis and to candidly accept that the courts declined to bow to Parliament's will? I know of no rule of law or logic which would make judicial disobedience more palatable simply because it is done covertly.

I have previously suggested that, on a proper analysis of Anisminic, the judiciary asserted, or at least came close to asserting, that the courts would not enforce a statutory provision which effectively required them to surrender their capacity to review the decisions of an all-powerful executive. To have done so would have been to cast the courts in an ineffective, if not impotent, role in the face of parliamentary supremacy. By proclaiming that they would not enforce such laws, the House of Lords effectively circumscribed the legislative supremacy of Parliament. ${ }^{90}$ This view has also gained greater prevalence today. In the 1994 edition of Wade and Forsyth's Administrative Law, for example, the learned authors explain Anisminic in similar terms. They suggest that the House of Lords simply refused to enforce the ouster provision and that, in doing so it applied "a presumption which may override their constitutional obedience, namely that

89 Anisminic Ltd v Foreign Compensation Commission [1969] 2 AC 147 [Anisminic].

90 "Administrative Law" above n 4, 177. 
jurisdictional limits must be legally effective". "This is tantamount to saying", the learned authors continue, "that judicial review is a constitutional fundamental which even the sovereign Parliament cannot abolish". 91

Such restraint is part of the judicial discipline which extends beyond mere adherence to precedent and encompasses all the constraints which operate to curb an arbitrary or excessive exercise of judicial power. These constraints are not to be found in the confining rigours of a rigid doctrine of precedent but in the adjudicative discipline under which the judiciary works. Any decision is subject to the correcting influence of the formal appellate process and the informal pressure of judicial peers requiring justification in accordance with recognised legal norms and established judicial techniques, craftsmanship and style. Decisions must withstand the evaluation of an independent profession, the critical appraisal of the academic community and, at times, the vigorous scrutiny of the community itself. Ultimately, the compelling constraint is "the felt presence of all the factors which make up the discipline which binds the judiciary". ${ }^{92}$

Anisminic, involving, as it did, the exclusion of the jurisdiction of the courts to supervise the legality of the exercise of executive power, justified resistance. The executive acting through a government - or parliamentary - majority cannot be permitted to put itself beyond the reach of the rule of law. A case where the High Court of Australia intervened, however, in a manner indicative of an evacuation of judicial restraint should not go unchecked. Discerning an implied jurisdiction to protect human rights in the Australian Constitution, the High Court in Australian Capital Television v Commonwealth of Australia ${ }^{93}$ struck down part of a Commonwealth Act. ${ }^{94}$ The legislation provided for free air time for all political parties and permitted unrestricted journalistic coverage, but barred broadcasters from broadcasting political advertisements for a period prior to an election. The legislature's objective was to "cleanse" the electoral process by limiting expenditure on

91 H W R Wade and C F Forsyth Administrative Law (7 ed, Oxford University Press, New York, 1994) 737. This perception can be traced back to the fourth edition of Wade on Administrative Law (4 ed, Oxford University Press, New York, 1977) 573.

92 Hon E W Thomas A Return to Principle in Judicial Reasoning and an Acclamation of Judicial Autonomy (1993) VUW Law Review Monograph 5, 54-56 [Return to Principle]. See also Malcolm M Feeley and Edward L Rubin Judicial Policy Making and the Modern State (Cambridge University Press, Cambridge, 1998) 209-211; 241-248; and 353-361.

93 Australian Capital Television Pty Ltd v Commonwealth of Australia (1992) 177 CLR 106 [Capital Television].

94 Pt 111D of the Broadcasting Act 1942, introduced by the Political Broadcasts and Political Disclosures Act 1991 (Cth). 
political campaigns. The effect of the legislation would have been to negate or reduce the advantage of political candidates or parties having wealthy backers able to buy up expensive television advertising time to promote their chosen candidates or parties. The High Court accepted that it had no express power to review primary legislation, but held that a power to do so was implied in the constitutional primacy of representative government. As representative government depends on the full and free communication of ideas, any legislation which obstructs the fullest possible flow of opinion in the electoral process was held to be unconstitutional. ${ }^{95}$

I have no quibble with the High Court's discovery that the Court's jurisdiction to preserve representative government is implied in the 92 year old Constitution. But the exercise of the jurisdiction in that case represented a provocative lack of judicial restraint. Democracy demands a free flow of ideas, but it is difficult to accept that legislation which seeks to provide a more level playing field in the public expression of those ideas is damaging to the preservation of representative government. Indeed, it may be credibly argued that such a measure would be beneficial in achieving a more truly representative democracy. As Sedley has observed, the High Court assumed a symmetry between freedom of speech and freedom of information which simply does not exist. ${ }^{96}$

The Capital Television case undoubtedly provides hard evidence for those who proclaim that judicial restraint must be construed to mean judicial abstinence. The courts, it will be said, cannot be trusted to get it right. But it can do no harm when advancing the possibility of judicial review of extreme legislation to acknowledge that the judiciary, no less than the legislature, is not infallible and that judicial views as to what is fundamental may and will differ. Such experience simply serves to reinforce the need for the utmost caution before questioning the legislation of a duly elected government. The exercise of this residual power when it is not strictly necessary to preserve the basis of representative government, or the rule of law, or fundamental human rights is a usurpation of power which is every bit as unconstitutional as would be Parliament's attempt to destroy democracy or override those rights by legislation.

\section{A Toward a More Positive Jurisprudence?}

An essential part of my thesis holds that a less unquestioning acceptance of the doctrine of parliamentary legislative supremacy will have a favourable impact upon the

95 For a full discussion of this case, see Sedley, above $\mathrm{n} 4$, 393-394. 
judiciary's traditional function. Both a more positive jurisprudence and a better working relationship between Parliament and the courts will emerge.

I am indebted to Professor Jaffe for my perception of the optimum working relationship. There is the potential for a "fruitful partnership and interaction" between Parliament and the courts "in the law-making business together ... continually at work on the legal fabric of society". ${ }^{97}$ Within the limits set by the constitution, Parliament's legislative supremacy will hold sway. The legislature can, if it so chooses, legislatively correct decisions of the courts

97 Louis L Jaffe English and American Judges as Lawmakers (Clarendon Press, Oxford, 1969) 20, 75 [Judges as Lawmakers]. Lord Devlin criticises this view in The Judge (Oxford University Press, Oxford, 1979) 16-17 [The Judge] to the effect that, to be effective, it would require the two institutions to converse is self-evidently weak. Jaffe's own acknowledgement of the difficulties in encouraging the judiciary to make law which must be undone by the legislature is more telling (Judges as Lawmakers, above, 20). The author has given judicial recognition to Professor Jaffe's concept of a "fruitful partnership" between Parliament and the courts: $R v$ Hines [1997] 3 NZLR 529, 581-582; Fulcher v Parole Board (1997) 15 CRNZ 222, 242. 
it does not like. ${ }^{98}$ For their part, the courts will abide Parliament's legislative supremacy without sacrificing their independent role to develop the law to serve the ends of justice and meet the current needs and reasonable expectations of the community. Respect for the separate roles of Parliament and the courts can be accomplished without compromising this judicial function. Indeed, the fundamental constitutional principle of judicial independence exists to ensure that this function is impartially and fearlessly exercised. ${ }^{99}$

Leaving open the possibility that Parliament's legislative supremacy is subject to ultimate review by the judiciary need not create a rift or tension between Parliament and the judiciary. In the first place, as already stressed, the circumstances which could lead to the court's intervention are by definition extreme. Parliament's legislative supremacy would continue to be the rule, with Parliament enacting laws and the courts interpreting those laws. In the second place, Parliament and the courts share the same commitment to the fundamental tenets of democracy. Both owe allegiance to the constitutional imperative of representative government, the rule of law and fundamental human rights. Tension will only arise should the commitment of one or the other suffer an unconstitutional lapse.

It would, of course, be unrealistic not to accept that antagonism may be expressed by some politicians and others hostile to the possibility of Parliament sharing the power which the people have delegated to the three arms of government. On analysis, this antagonism would appear to stem either from a failure to realistically distinguish between Parliament, the institution, and the government or majority in Parliament; or from an unsophisticated version of democracy which does not look beyond the concept of majoritarian rule; or from an unrealistic perception of Parliament as the sole law-making body and a consequential resentment of the court's acknowledged law-making function. With these misconceptions brushed to one side, there is no reason why a working relationship cannot be developed between Parliament and the courts which is in no way impaired by the possibility that the courts may have the ultimate power to declare oppressive or extreme legislation invalid. ${ }^{100}$

Working within this framework, the possibility of judicial review of oppressive legislation at a future date should be beneficial. It is salutary for Parliament to know that it

98 Return to Principle above n 92, 29. Recent cases where Parliament has reversed the Court of Appeal are $R v$ Hines [1997] 3 NZLR 529, by ss 13B-13J of the Evidence Act 1908, inserted by s 3 of the Evidence (Witness Anonymity) Amendment Act 1997, and Daniels $v$ Thompson [1998] 3 NZLR 22, by s 396 of the Accident Insurance Act 1998.

99 Hon E W Thomas "Parliamentary Supremacy and the Judicial Function" (1996) 112 LQR 177.

100 Return to Principle above n 92, 68. 
works within legislative limits which are fixed, not by the majorities or coalitions within Parliament that may come and go, but by the permanent constraints of a constitution. A mature conception of democracy accepts that citizenship in a free and democratic society is founded on the observance of the rule of law and basic human rights, and that these qualities must therefore be placed beyond serious legislative encroachment. ${ }^{101}$

The greatest benefit, however, can be expected to accrue to the judiciary. Blind adherence to the doctrine of parliamentary supremacy has had a negative impact on the performance of the judicial function. To refer to Professor Jaffe again; "A judiciary which too much reminds itself that its power is limited by the dogmas of Parliamentary omnicompetence, Parliamentary supremacy, and Parliamentary responsibility may lose the will to exercise ... [its] great historic function". He suggests that, while the courts have played a great role in the development of an unwritten constitution, above all in creating safeguards against the abuse of executive and administrative power, ${ }^{102}$ judges who insist on Parliament's monopoly of law and policy making will be loathe to check the executive. ${ }^{103}$

The distinguished Professor is surely correct. Unthinking adherence to the doctrine of parliamentary supremacy can induce a debilitating subservience which must necessarily impinge on the judiciary's traditional function. It is all too easy for judges who are faced with a "hard" case for which there is no direct rule or precedent to attribute the responsibility for the harshness of the outcome to Parliament. Rational legal analysis is abandoned in favour of leaving the problem to the legislature. The injustice which results, or the fact that the law fails to meet the current needs and reasonable expectations of the community, can be blamed on that institution. This reasoning - or unreasoning - process may occur even where there is little or no prospect that Parliament will legislate to remedy the problem. ${ }^{104}$

What has happened is plain to see. Judges, lawyers and academics have tended to vest Parliament's legislative supremacy with a law-making monopoly. They have confused Parliament's monopoly to enact laws by legislation with a monopoly to make law and

101 "Law, Politics and Revolution" above n 11, 449.

102 "Judges as Lawmakers" above n 97, 19.

103 "Judges as Lawmakers" above n 97, 26.

104 This approach contrasts sharply with the attitude of Lord Denning that every unjust decision is a reproach to the law or to the judge who administers it: Re Vandervell's Trusts (No 2) [1974] Ch 269, 322, referred to by the author in "Lord Denning 1899-1999: A Brief Soliloquy" [1999] NZLJ 92, 93. 
thereby overlooked or discounted the court's own law-making role. It is now universally 
accepted that judges make law. ${ }^{105}$ As Lord Reid said, "... we do not believe in fairy tales any more". 106 Once it is accepted that judges make law, the question whether a proposed law change or development should be accomplished within the bounds of the common law or better left to Parliament can be asked without doing harm to the doctrine of parliamentary supremacy. The judicial $\sin$ is not to ask the question at all, but to automatically assume that, being a change or development in the law, it is necessarily Parliament's business.

To put the point another way; the decision whether to leave a proposed change or development in the law to Parliament is a decision which the court must make in the context of the particular case. It can make that decision mechanically, relying upon a perception of Parliament's legislative supremacy which confers a law-making monopoly on that institution, or it can make a deliberate decision having regard to the factors which favour leaving the proposed change or development to Parliament and the factors which favour a judicial solution. Such an exercise is the inevitable outcome of the fact that judges make law. A decision whether or not to leave the matter to Parliament is inescapable; what is required is a deliberate and reasoned decision.

The factors which favour leaving a proposed change or development in the law to Parliament are well rehearsed. Parliament will be favoured if the particular law is deeply entrenched, or controversial, or generates policy considerations for which the legislature should be held accountable. By and large reforms which might have an undesirable retrospective effect should be left to Parliament. So, too, will law reform which requires extensive research and resources which are beyond the courts' purview and function. The courts, on the other hand, will be preferred where the area of law has historically been judge-made law. Of course, the description "historical" should be used to refer back beyond more recent times when Parliament has been called upon to remedy deficiencies deficiencies often created or permitted by the nonfeasance of the judiciary - in the general law of contract, tort, equity, administrative law, or the like. In these areas of law, change will generally be able to be made by reference to basic principles and, in such

105 It is unnecessary to enter upon a dissertation to establish that judges make law. No judge or serious lawyer or scholar suggests it is otherwise. The author has dealt at length with the topic in Return to Principle above $\mathrm{n} 92$. Those who persist in disregarding the evidence and holding to the discredited declaratory school of thought may be persuaded by an anecdote about a Mr Choate addressing an American court. Mr Choate had stated the law as he knew it. The Judge said, "No, Mr Choate, that is not the law". "With the greatest respect Your Honour", replied Mr Choate, "it was the law until Your Honour just spoke". (Related in 31 ALJ 249.)

106 Lord Reid "The Judge as Lawmaker" (1972) 12 JSPTL, 22. 
circumstances, the courts should not hesitate to apply those principles to reshape or enlarge or change the direction of the law. It has been observed that these areas of law are likely to bear a close correlation with a general legislative disinterest in reforming that law. 107

The fact that there are many things which Parliament can do better than the courts does not invariably mean that the courts should abstain. In some circumstances, a tentative lead may be required. In other circumstances it may be clear that Parliament will not be motivated to make the change, at least, within the foreseeable future. This may be because the needed change lacks "political" appeal. Then, there are many things Parliament and the courts can do together, with Parliament providing the lead. The courts, for example, have the opportunity to implement and develop the principles which have received the imprimatur of Parliament and of public opinion. 108

Legislation, particularly remedial legislation, must necessarily be a fruitful reservoir of legal principles. Both in theory and in practice, legislation is likely to provide a guide to the standards, needs and expectations of the community. Consequently, the Court should be quick to have regard to the principles embodied in the laws which the people's representatives have chosen to enact for their benefit, and to adopt or apply any discernible trend in the direction of legislation which is relevant to the subject matter of the case in question. In this context it is to be noted that, with few exceptions, the legislature has not sought to obtain abstract justice from the courts by providing particular rules. In enacting remedial legislation it has generally been content, presumably reflecting acceptance by the community, to vest judges with wide discretionary powers with either no criteria or limited criteria for the exercise of the discretion. ${ }^{109}$ The judges are expected to implement the policy of the legislature and to that end are left to work out the principles which will guide them in the exercise of the discretion. ${ }^{110}$

107 Return to Principle above n 92, 28-30, 67.

108 Judges as Law Makers above n 97, 75-76.

109 See for example Contributory Negligence Act 1947; Law Reform Act 1936; Minors Contract Act 1969; Illegal Contracts Act 1970; Contractual Mistakes Act 1977; Contractual Remedies Act 1979; Contracts (Privity) Act 1982; and the Fair Trading Act 1986. See also, Return to Principle above $\mathrm{n}$ $92,7$.

110 Sir Kenneth Keith has pointed out that judges are authorised to determine a matter "as they think fit" in over 3,000 statutory provisions and that the phrase "just and equitable" is used on some 181 occasions in commercial and property legislation; K J Keith "The Law, the Constitution and Legal Education in the Twenty-First Century" (2000) 31 VUWLR 83, 99. 
Free from unwarranted deference to Parliament's legislative supremacy or monopoly, therefore, a more positive jurisprudence may emerge. Only a brief sketch or outline of the direction that positive jurisprudence might take is possible. In respect of cases where a statute falls for interpretation there may be a greater willingness to accept that, in most cases, the legislature has not actually addressed the point at all and therefore had no specific intent in respect of the question. In such circumstances, the literal approach, exemplified by Lord Devlin's exhortation; "... in the end the words must be taken to mean what they say and not what the interpreter would like them to say"111 can lead to pedantic results and the impression that the courts are frustrating rather than furthering the legislature's objectives. Pollock's characterisation of the approach of judges to statutory construction seemingly lingers on. In his Essays on Jurisprudence and Ethics, the distinguished jurist stated: ${ }^{112}$

Parliament generally changes the law for the worse, and ... the business of judges is to keep

the mischief of its interference within the narrowest possible bounds.

No such approach will do today. Statutory problems must be worked out in the courts as they arise by the resourceful use of policies for which there is public support. Judges must approach questions of construction positively determined to give effect to the legislature's policy. With a less literal, unimaginative reading of statutes by the courts, the statute books may become less prolix and unwieldy; less full of minutiae trying to do that which the judges should be doing. ${ }^{113}$

Within the bounds of administrative law the courts may give greater prominence to the principle of accountability in the exercise of public power. Liberated from its ultra vires base, the various grounds of judicial review can be developed on a more coherent basis. Even Wednesbury ${ }^{114}$ may cease to mean that an unreasonable decision is reasonable if it is made by an elected body.

Equity probably remains the most fertile ground for the development of the law to meet modern demands. Introduced to mitigate the rigour of the law, equity has been cramped by the very formalism which overtook the common law and inspired the judges of old to turn to equity. Equitable principles have become ossified with rules, and broad

111 The Judge above $\mathrm{n} 97,14$.

112 H Z Pollock Essays on Jurisprudence and Ethics (MacMillan, London, 1882) 85; refuted in Commissioners of Inland Revenue v McGuckian [1997] 3 All ER 817, 824 per Lord Steyn.

113 Judges as Lawmakers above $\mathrm{n} 97,76$.

114 Associated Provincial Picture Houses Ltd v Wednesbury Corporation [1948] 1 KB 223. 
principles which defy close definition or classification continue to be resisted. ${ }^{115} \mathrm{~A}$ judicial approach which recognises that equity exists to ameliorate unjust, harsh and unhelpful laws would be a welcome return to the precedent of the past.

In the domain of the common law unaffected by statute, a domain which is still vast, the courts may revert to a principle-oriented approach divorced from an inflexible and outdated application of the doctrines of precedent and stare decisis. ${ }^{116}$ Is it not possible, for example, for the courts to yet incorporate a general requirement of good faith in the making and performance of contracts? ${ }^{117}$ Lord Mansfield may be long since dead and buried but his spirit is not entirely extinguished. To that great law Lord, good faith was "the governing principle ... applicable to all contracts and dealing". ${ }^{118}$ Other examples press the community's patience.

\section{CONCLUSION}

The keen reader will have observed that this paper might well have begun where it has ended, with a plea for a more positive jurisprudence in which the relationship of Parliament and the courts is in the nature of a fruitful partnership in the law-making business together, but with Parliament the dominant partner working within the limits of the constitution. The single most debilitating influence on that more positive jurisprudence has been the judiciary's fulsome deference to the sovereignty of Parliament. With a grip of iron the concept has strangled the coherent development of the law. Consequently, the more widely it is accepted that there is no magic in the notion of parliamentary legislative supremacy or, at least, the possibility is accepted that the courts may in certain circumstances intervene to overrule Parliament and protect the constitution, the less likely it is that this unnecessary judicial deference will persist. Blind or mechanical adherence to the doctrine of parliamentary supremacy will have been dealt a telling blow. Liberated from an unnecessary obeisance to the doctrine and its collateral perception of Parliament as the sole law-making institution, the courts can develop a more positive jurisprudence which will better serve the ends of justice and better meet the current needs and reasonable expectations of the community.

The portent is favourable. A number of factors suggest a reappraisal of our unwritten constitution. They are the contemporary and universal emphasis on fundamental human

115 Hon E W Thomas "An Affirmation of the Fiduciary Principle" [1996] NZLJ 405.

116 Return to Principle above $\mathrm{n} 92$.

117 See Livingstone v Roskilly [1992] 3 NZLR 230, 237-238.

118 Carter v Boehm (1766) 3 Burr 1905. 
rights; controversy as to the status of the Treaty of Waitangi and the British concept of sovereignty; major changes in the governmental structure and the impact of MMP on the notion of majoritarian government; and the contemporary development of judicial review as a substantive principle of the common law.

As I have advocated in this paper, rather than discuss the issue in the abstract, it is preferable to leave the question whether the courts can review the validity of extreme legislation to be decided by the judges if and when legislation is enacted which places in jeopardy the basis of representative government, the rule of law or fundamental human rights. The resulting uncertainty or inconclusiveness itself serves the constitutional function of ensuring a balance in the distribution of public power between Parliament and the courts, better than would the present resolution of the question in favour of one or the other of the two institutions. The possibility that the courts may review the validity of extreme legislation is part of the ongoing development of a dynamic constitution rather than a reassertion of the authority of cases long since gone and regularly disavowed.

The fundamental plank of the constitution is the sovereignty of the people. Its democratic imperative is representative government. That sovereignty and that imperative can only be constitutionally protected by the adjudication of an independent judiciary. But, it is to be stressed, the decision whether or not to review legislation is, and can only be, a decision for the courts to make. It therefore falls to the judiciary to exercise the power with caution and restraint.

Let me conclude with this thought. When contemplating our Lady of Justice, we tend to focus on the scales which she holds in her outstretched left hand. We should bear in mind that in her right hand she bears a sword. Is it not possible that in the last resort our Lady of Justice might not be moved to throw aside her blindfold and wield the sword to defend the sovereignty of the people against unjust oppression? May not oppressive legislation offend her basic instinct for justice no less than oppressive executive acts carried out under the purported authority of legislation?

Accepting the possibility that the courts may intervene to review oppressive legislation, the judiciary, in carrying out their traditional function, are then likely to pay due respect to Parliament's legislative supremacy without according it a subservience which has tended to hamper the law's ability to develop to meet the needs and reasonable expectations of the community and to render to all the justice that is their due. Such independence is required if the law is to protect the individual, either alone or as a congruent grouping, from the iniquities of exploitation in all its forms. It may well be that the law has no higher calling than to defend the poor against the mighty, the powerless against the powerful, and the weak against the strong. 
